\title{
418 医療用断層写真を用いた三次元六面体有限要素モデリング
}

Three Dimensional Hexahedral Meshing Using Medical CT Images

\author{
正 村瀬晃平（近畿大学工学部）
}

学 山田裕士（近畿大学工学部）

Kouhei MURASE and Hiroshi YAMADA

School of Engineering, Kinki University,

1 Takayaumenobe, Higashihirosima

Keywords: Three Dimensional Finite Element Model, Fractal Dimension, Medical CT Image

\section{1.はじめに}

有限要素解析においては解析精度などの理由により、工業 製品では六面体要素や二次要素によるメッシュ分割が利用 されている。しかしながら、生体組織は複雑な三次元形状を 有しており、モデリングには多大な労力が必要である $1,2,6$ 。 有限要素モデルが元形状をどれだけ忠実に再現しているか を評価する方法についても現在も様々な研究が行われてい

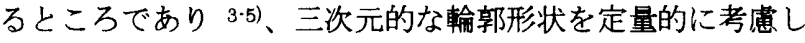
つつモデルを構築することは非常に困難である。

本研究では、輪郭形状精度を維持しつつモデル規模を低減 させるために、六面体要素による三次元有限要素モデリング を行なう汎用的手法の開発に関して基礎的研究を行った。

\section{2.方法}

複雑な輪郭形状を有する自由物体の例として人膝関節 を対象に採りあげた。医療用 CT 画像データ(ピッチ $5 \mathrm{~mm}$ ) をもとに画像処理をおこない、関節近傍の輪郭点を抽出した。 輪郭を構成する特徴点をスプライン補間により連結させ、再 構築された輪郭線を積層することにより表面サーフェスモ デルを生成する。断面輪郭はどの部分においてもなめらかに 形状が変化していると仮定し、急激に輪郭形状の変化が観察 された領域については、別方向からの CT 画像情報を重ねあ わせることとした。サーフェスモデルは三角形パッチにより 構成される。

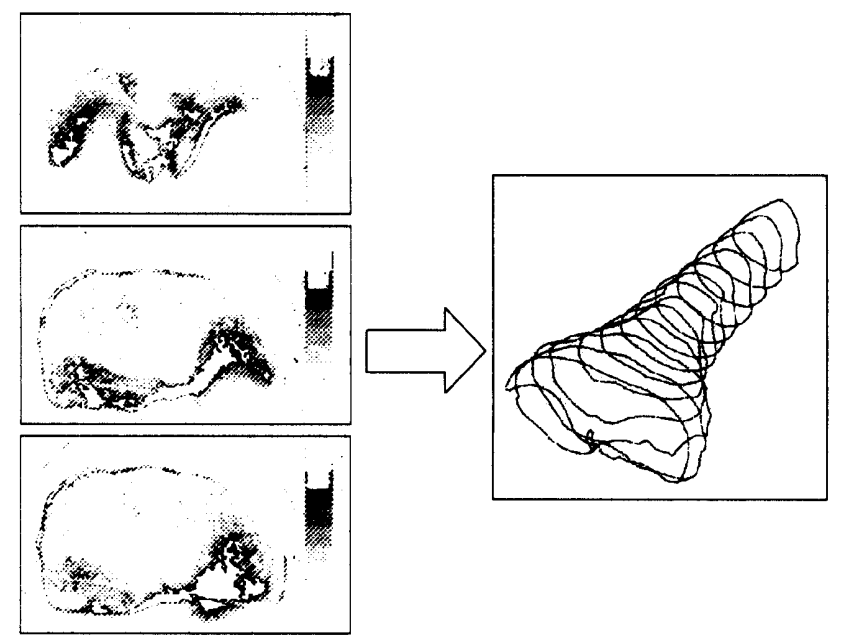

Fig.1 Surface construction from CT Image
本研究では、あらかじめ六面体要素で分割した有限要素メ ッシュ(シードメッシュ)をモデル内部で膨張させることで、 モデル要素を生成する手法を試みた。膨張が進みモデル輪郭 面と交差したときには処思法による接触判定を行い、モデル 内部に要素を充填する。球型の三次元シードメッシュを使用

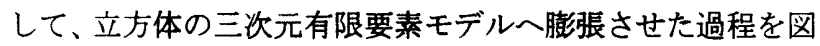
2 に示す。

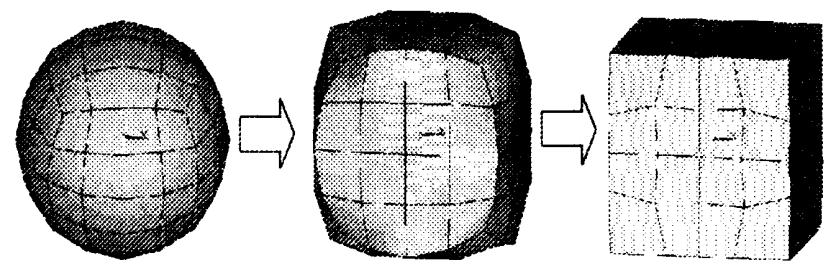

Fig.2 Expansion form a ball to cube FE mesh.

今回は対象物の形状を考廥し、カプセル型のシードメッシ ユを用意して要素生成を行った。図 3 にシードメッシュのサ 一フェス内での初期レイアウトを示す。有限要素モデルの膨 張は、モデルを徐々に境界面に接触させる繰り返し計算をお こなうことにより収束させた。

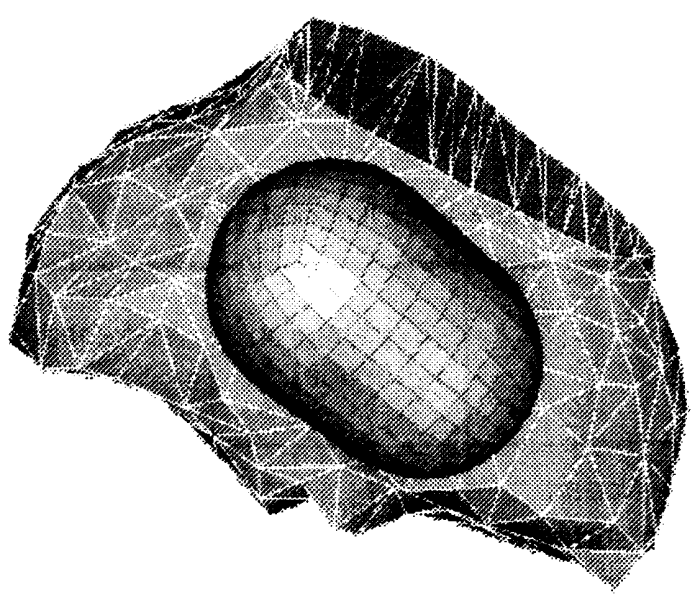

Fig. 3 Location of 'SEED' FE mesh in tibia surface

〔No.03-26〕日本機械学会第 16 回計算力学講演会講演論文集〔2003-11.22 24・神戸市〕 


\section{3. 結果・考察}

作成された脛骨部の六面体メッシュモデル、および同領域 をデロー二法による四面体メッシュで構築した脛骨プラト 一部のモデルを図 4 に示す。六面体メッシュモデルの輪郭形 状は四面体メッシュモデルとほぼ等しく、表面における節点 配置にも目立った粗密は認められなかった。
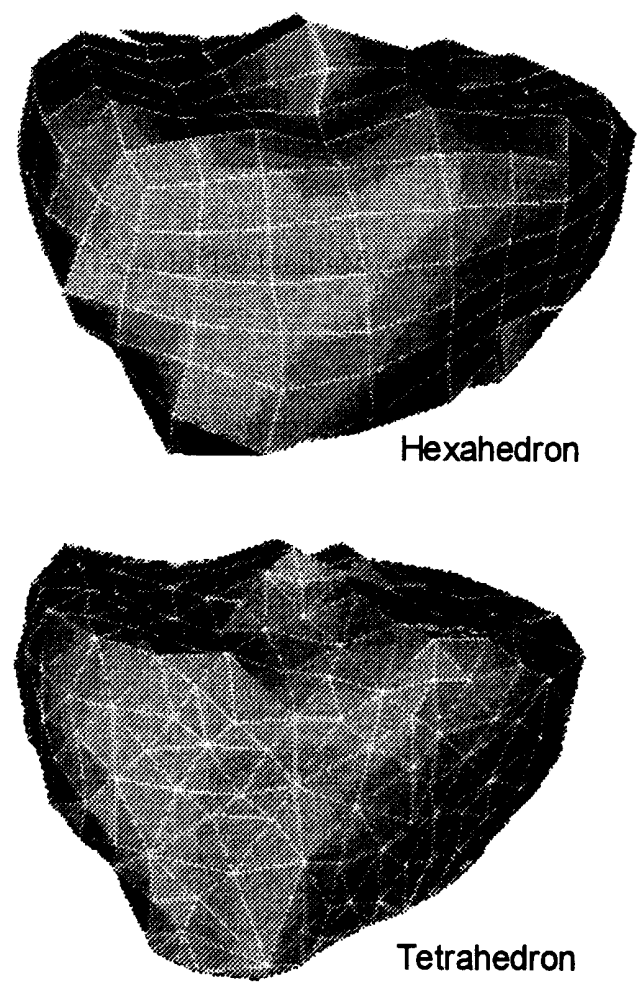

Fig.4 Three dimensional tibial FE mesh

表 1 に六面体充填有限要素モデルと四面体構築モデルそ れぞれの節点数および要素数を示す。今回は四面体構築モデ ルの表面節点数をシードモデルの表面節点数とほぼ同数に なるように作成している。六面体メッシュで充填を行ったモ デルでは四面体要素モデルに比べ節点がほぼ等しいのに対 して、要素を1/6以下に抑えられている。本手法ではあらか じめ要素数が決定されるため、解析に必要な時間やデー夕量 が同定しやすい。またモデル構築時の節点数がさらに增加し メッシュが細密化される場合、要素数の差はさらに大きくな ると考えられる。

Table 1 Result of mesh generation

\begin{tabular}{|c|c|c|}
\hline & $\begin{array}{c}\text { Tetrahedron } \\
\text { model }\end{array}$ & $\begin{array}{c}\text { Hexahedron } \\
\text { model }\end{array}$ \\
\hline $\begin{array}{c}\text { Nodes } \\
\text { (on surface) }\end{array}$ & 602 & 572 \\
\hline Element & 6827 & 1120 \\
\hline
\end{tabular}

シードモデルの要素数をさらに低減して膨張充填を行っ た場合、脛骨プラトー部、大腿骨顆部など凹凸が激しい領域 では表面輪郭と十分に接触しない場合が見られた。今後、輪 郭形状を定量的に評価することとあわせ、シードモデルを複 数配置した場合の充填法、ならびに領域に応じてモデル構築 に必要な節点数および要素数を決定する手法を開発する必 要がある。

\section{4. まとめ}

本研究では膝関節部分に六面体要素で充填することでモ デルの要素数を四面体要素を構築する場合にくらべ大幅に 要素数を低減することができた。本提案手法は、複雑な三次 元形状に対して六面体メッシュによる有限要素モデルをお こなうための一手法として有効であると考えられる。

\section{参考文献}

1) Harada $\mathrm{T}$, et al : An Aesthetic Curve in the Field of Industrial Design, proc.IEEE symposium on visual Language, pp.38-47,1999.

2）伊能、鈴木、宇治橋、槙 : X 線 CT データに基づく骨体 の応力解析(Dekaunay Tringulationj を利用した固体別 モデリング)，第 11 回バイオエンジニアリング講演会講 演論文集(No.o1-16)，pp.39-40,2001.

3）村瀬ほか: 生体三次元有限要素モデルの形状忠実度評価 法, 日本臨床バイオメカニクス学会誌, Vol24(掲載決定), 2003.

4）村瀬、奥本、水谷 : 生体力学解析のための三次元有限要 素モデルに関する基礎的研究，第 13 回計算力学講演会 論文集, pp.279,2001

5) K.Murese : Improvement of shape fidelity of three dimensional FEM model by multi-directional slice, 10th Int. Conf..Biomed.Eng. Singapore, pp .519,2000

6）大村、坂本ほか：ベーシスベクトル法による生体骨モデ ルの形状変換, 2003 年度年次大会講演論文集, 9-10, 2003. 